\title{
PENDAMPINGAN MASYARAKAT ADAPTASI KEHIDUPAN BARU DALAM MENCIPTAKAN KAWASAN TANGGUH BENCANA COVID-19 STUDI PADA FASILITAS UMUM KOTA KEDIRI
}

\author{
*Ajie Hanif Muzaqi' ${ }^{1}$, Heylen Amildha Yanuarita², Suwarno³, Fauziah \\ Hanum $^{4}$
}

1, 2, 3,4 Program Studi Ilmu Administrasi Publik Fakultas Ilmu Sosial dan Ilmu Politik Universitas Kadiri

*email : ajiehanif@unik-kediri.ac.id

\begin{abstract}
Vigilance and discipline in implementing health protocols during the Covid-19 pandemic have an important role in preventing the spread of Covid-19 virus. Something that can be done is to provide assistance in a persuasive, participatory, and integrative manner. Recently, the people of Kediri City, especially those in public facilities, have not been disciplined in implementing health protocols. By providing assistance, it is hoped that the community will be more disciplined and vigilant so that they can create a community that cares about the environment which will have implications for the resilient area of the Covid-19 disaster ini Kediri. This assistance activity was carried out in August 2020 which focused on 4 (four) public facilities such as the Bus station, Selomangkleng Cave, Sekartaji Park, and Bandar Traditional Market. This activity uses socialization and counseling approach persuasive manner. Based on the results of the evaluation, many people have not used personal protective equipment such as masks and shops that have not provided a hand washing area. However, if the cadres care for Covid-19, it is hoped that the 4 (four) areas will increase their status to become a resilient area for the Covid-19 disaster.
\end{abstract}

Keywords: Accompaniment, Disaster Resilient Area, Covid-19.

\begin{abstract}
ABSTRAK
Kewaspadaan dan kedisiplinan dalam menerapkan protokol kesehatan di tengah pandemic Covid19 ini berperan penting dalam mencegah penyebaran virus Covid-19. Salah satu cara yang bisa dilakukan adalah dengan melakukan pendampingan secara persuasif, partisipatif, dan integratif.. Belakangan ini, masyarakat Kota Kediri khususnya di lokasi-lokasi fasilitas publik belum disiplin dalam menerapkan protokol kesehatan yang ada. Dengan pendampingan yang dilakukan diharapkan masyarakat lebih disiplin dan waspada sehingga dapat membentuk kader-kader peduli lingkungan yang nantinya akan menciptakan kawasan Tangguh Bencana Covid-19 di Kota Kediri. Kegiatan pendampingan ini dilaksanakan pada bulan Agustus 2020 yang berfokus pada 4 (empat) lokasi fasilitas publik yaitu Terminal Kota, Obyek Wisata Goa Selomangkleng, Taman Sekartaji, dan Pasar Bandar Kota Kediri. Kegiatan ini menggunakan metode sosialisasi dan penyuluhan secara persuasif. Berdasarkan hasil evaluasi kegiatan yang telah dilakukan banyak masyarakat yang belum mengunakan alat pelindung diri seperti masker serta tempat usaha yang belum menyediakan area cuci tangan. Namun apabila sudah di bentuk kader-kader peduli Covid-19 di harapkan 4 (empat) kawasan tersebut dapat meningkat statusnya menjadi kawasan tangguh bencana Covid-19.
\end{abstract}

Kata Kunci: Pendampingan, Kawasan Tangguh Bencana, Covid-19 


\section{PENDAHULUAN}

Berbagai upaya telah dilakukan Pemerintah baik Pusat dan Daerah untuk menekan angka korban terkait dampak bencana Covid-19. Saat ini pemerintah dihadapkan pada masalah baru selain jumlah kasus yang tertular bencana Covid-19, sosial dan ekonomi pun terus mengalami dampak buruk dan harus segera dipulihkan. Salah satu upaya yang bisa di lakukan oleh pemerintah saat ini untuk mengembalikan keterpurukan ekonomi dan sosial akibat bencana Covid-19 adalah menerapkan konsep new normal atau adaptasi kehidupan baru.

Kehidupan normal baru atau "new normal life" merupakan dua hal tentang bagaimana memulai 2 (dua) cara hidup baru yang berlandaskan kesadaran dan disiplin. Masyarakat diharuskan memiliki sikap sadar dan disiplin dengan cara hidup baru yang lebih terfokus pada kesehatan dan keselamatan diri sendiri, keluarga dan orang lain disekitarnya. Secara teoritis konsep "new normal" sendiri belum ada definisi yang resmi, namun berdasarkan Ketua Tim Pakar Gugus Tugas Percepatan Penanganan Covid-19, Wiku Adisasmita yang dikutip dalam Kompas menyatakan new normal adalah perubahan prilaku untuk tetap menjalankan aktivitas normal. Namun, perubahan tersebut ditambah dengan menerapkan protocol kesehatan guna mencegah terjadinya penularan Covid-19 (Kompas, 26 Mei 2020).

Protokol kesehatan yang di maksud menurut Keputusan Menteri Kesehatan Republik Indonesia Nomor HK.01.07/MENKES/328/2020 Tentang Panduan Pencegahan dan Pengendalian Corona Virus Disease 2019 (Covid-19) di Tempat Kerja Perkantoran dan Industri dalam Mendukung Keberlangsungan Usaha pada Situasi Pandemi seperti menggunkana masker, menjaga jarak lebih dari 1 (satu) meter, menjaga etika bersin dan batuk, cuci tangan 20 detik, dan lain lain. Namun pada kenyataanya di Indonesia, protocol tentang kesehatan belum di terapkan secara optimal.

Tingkat kesadaran dan disiplin masyarakat Indonesia terhadap protocol kesehatan masih rendah dan diperlukan sanksi tegas yang mengaturnya. Pemberian sanksi tegas akan membentuk masyarakat yang lebih disiplin dan patuh terhadap peraturan. dalam menerapkan new normal, beberapa lokasi yang beresiko seperti sekolah, mall, tempat wisata dan panti jompo harus sepenuhnya dididik dan diberdayakan dibawah konsep normal baru. Selain itu, sistem kesehatan juga harus disiapkan apakah sudah bisa melacak setiap kasus baru.

Dalam menerapkan new normal life ke masyarakat harus disosialisasikan sesuai karakteristik masyarakat di Indonesia. Menurut Rahardjo (2010) karakteristik masyarakat 
Indonesia berbentuk majemuk. Artinya karkteristik masyarakat majemuk lebih berpotensi terjadi konflik dan kontra. Dalam kondisi seperti ini diperlukan kemampuan seorang pemimpin baik di ruang lingkup yang kecil seperti RT dan RW atau ruang lingkup yang lebih besar seperti Negara untuk mensosialisasikan gaya hidup baru di tengah pandemic covid-19 agar pesan yang disampaikan dapat diterima dengan baik oleh masyarakat dan tidak menimbulkan perdebatan.

Menurut Maclever (2013) sosialisasi adalah proses mempelajari norma, nilai, peran, dan semua persyaratan lainnya yang diperlukan untuk memungkinkan berpartisipasi yang efektif dalam kehidupan sosial, Adapun manfaat adanya sosialiasi dalam masyarakat terbagi menjadi dua tahap, Bagi individu, sosialisasi berfungsi sebagai pedoman dalam belajar mengenal dan menyesuaikan diri dengan lingkungannya, baik nilai, norma, dan struktur sosial yang ada pada masyarakat di lingkungan tersebut. Bentuk sosialisasi bisa dilakukan lewat media komunikasi tradisional misalnya pertunjukan wayang bagi masyarakat di wilayah pedesaan, dan media sosial bagi masyarakat yang tinggal di wilayah perkotaan. Tujuannya agar hal ini mudah diterima oleh masyarakat.

Proses komunikasi menjadi unsur terpenting dalam efektivitas kegiatan pendampingan. Hal itu dikarenakan komunikasi merupakan unsur terpenting dalam menentukan berhasil atau tidaknya proses penyampaian pesan dari komunikator kepada komunikan yang menjadi tujuan utama dari komunikasi. Jika proses ini berjalan dengan baik, maka hasilnya juga pasti sesuai dengan yang diharapkan oleh komunikator (Herdiana, 2010). Dengan melakukan proses komunikasi yang tepat tujuan utama pendampingan dapat tersampaikan. Tujuan utama pendampingan ini tentunya untuk mengubah sikap atau prilaku masyarakat kepada pola hidup baru atau new normal dan bagaimana menerapkan protokol kesehatan yang baik dan benar. Sehingga upaya pemerintah dalam menekan korban dan memulihkan kembali perekonomian yang terpuruk akibat dampak Covid-19 dapat dicapai secara optimal dan dalam tempo yang singkat.

Salah satu kegiatan yang dilakukan oleh pemerintah dan akademisi dalam menguatkan pemahaman tentang adaptasi kegiatan baru adalah dengan melakukan pendampingan. Kegiatan pendampingan yang dilakukan oleh penulis bermitra dengan beberapa unsur terkait, seperti TNI, POLRI, dan Pemerintah setempat yang diwakilkan oleh kelurahan. Adapun fokus utama dari kegiatan pendampingan tersebut adalah di beberapa titik kerumunan warga di Kota Kediri atau fasilitas umum Kota Kediri. Dalam kegiatan pendampingan ini penulis dan mitra 
menerapkan beberapa himbauan tentang penerapan protokol kesehatan dan memonitoring serta mengevaluasi kepatuhan lingkungan tentang protokol kesehatan. Himbauan tentang protokol kesehatan yang diberikan terdiri dari : 1) Menggunakan masker, 2) Menyediakan tempat cuci tangan di beberapa tempat keramaian, 3) berjaga jarak atau physical distancing, 4) etika batuk dan bersin, dan 5) jangan menyentuh wajah. Adanya pendampingan ini diharapkan akan meningkatkan pemahaman masyarakat akan penyebaran virus Covid-19 dan tetap melaksanakan kegiatan secara normal serta menciptakan kawasan tangguh bencana Covid-19.

\section{METODE PELAKSANAAN}

Kegiatan pendampingan dilaksanakan pada 12 Agustus 2020 berlokasi Terminal Kota Kediri, Obyek Wisata Goa Selomangkleng, Pasar Bandar Kidul Kota Kediri, dan Taman Sekartaji Kota Kediri. Alasan ditentukannya 4 (empat) lokasi tersebut adalah karena lokasi tersebut menjadi fasilitas publik dan banyak berkumpulnya masyarakat. Pelaksanaan program pengabdian ini adalah dengan melakukan pendampingan dan penyuluhan terhadap pola kehidupan baru di masyarakat yang di fokuskan pada tempat-tempat keramaian di Kota Kediri. Pendekatan yang dilakukan adalah pendekatan partisipatif, transparan, dan integratif. Program yang dilaksanakan harus dapat dipertanggungjawabkan dalam hal ketetapan sasaran, waktu, pembiayaan, serta kualitas pekerjaan. Unsur yang terlibat dalam pelaksanaan kegiatan ini antara lain TNI, POLRI, Akademisi, ASN, dan perangkat keluarahan setempat. Pelibatan unsur pelaksana tersebut agar target sasaran dapat drealisasikan dan terciptanya kawasan tangguh bencana Covid-19 sehingga upaya pemerintah pusat dalam menghentikan penyebaran virus Covid-19 dapat terealisasi secara optimal.

\section{Ruang Lingkup Pekerjaan}

1. Memberikan bantuan pendampingan tentang adaptasi kebiasaan baru terhadap masyarakat di fasilitas umum Kota Kediri yaitu :
a. Pengamatan awal pada aktivitas masyarakat sehari-hari fasilitas umum
b. Penyusunan Rencana Kerja
c. Pelaksanaan

2. Membantu masyarakat dalam penyiapan alat-alat wajib di saat adaptasi kebiasaan baru seperti masker, hand sanitizer, dan sarung tangan.

3. Evaluasi dan monitoring kegiatan 


\section{HASIL DAN PEMBAHASAN}

Pendampingan dilakukan dengan tujuan mengedukasi masyarakat mengenai adaptasi kehidupan baru agar tetap aman namun produktif. Pelakasanaan dimulai dengan memetakan tempat-tempat berkerumunya masyarakat yang di fokuskan pada 4 (empat) lokasi yaitu terminal Kota Kediri, Taman Sekartaji, Obyek Wisata Goa Selomangkleng, dan Pasar Bandar Kota Kediri sebab diasumsikan di kawasan tersebut rentan penularan Covid-19. Selanjutnya penulis di damping oleh aparat setempat melakukan penyuluhan/ sosialisasi tentang pentingya menjaga protokol kesehatan. Penjelasan teknis tentang protokol kesehatan yang harus dipatuhi. Pendamping selain melakukan penyuluhan juga melakukan pelatihan tentang bagaimana menerapkan protokol kesehatan di tempat usaha. Selain itu, penulis dan mitra menertibkan tempat-tempat dan masyarakat yang belum memnuhi protokol kesehatan tujuannya adalah menegakan penertiban kepada agar tercipta kader-kader tangguh bencana Covid-19. Dilokasi tersebut juga dilakukan pembagian alat pelindung diri seperti masker serta tata cara penggunaan masker. Dan apabila terdapat tempat usaha yang belum menaruh tempat cuci tangan, mitra dan penulis akan membantu membuatkan tempat cuci tangan beserta sabun. Tegas dan disiplin menjadi kunci keberhasilan program pendampingan ini, sebab banyak masyarakat di Kota Kediri yang masih belum menerapkan protokol kesehatan. Kegiatan pendampingan ini mendapat respon positif dari masyarakat, sebab pendekatan yang dilakukan secara persuasive dan kekeluargaan. 
Berikut dokumentasi kegiatan pendampingan :

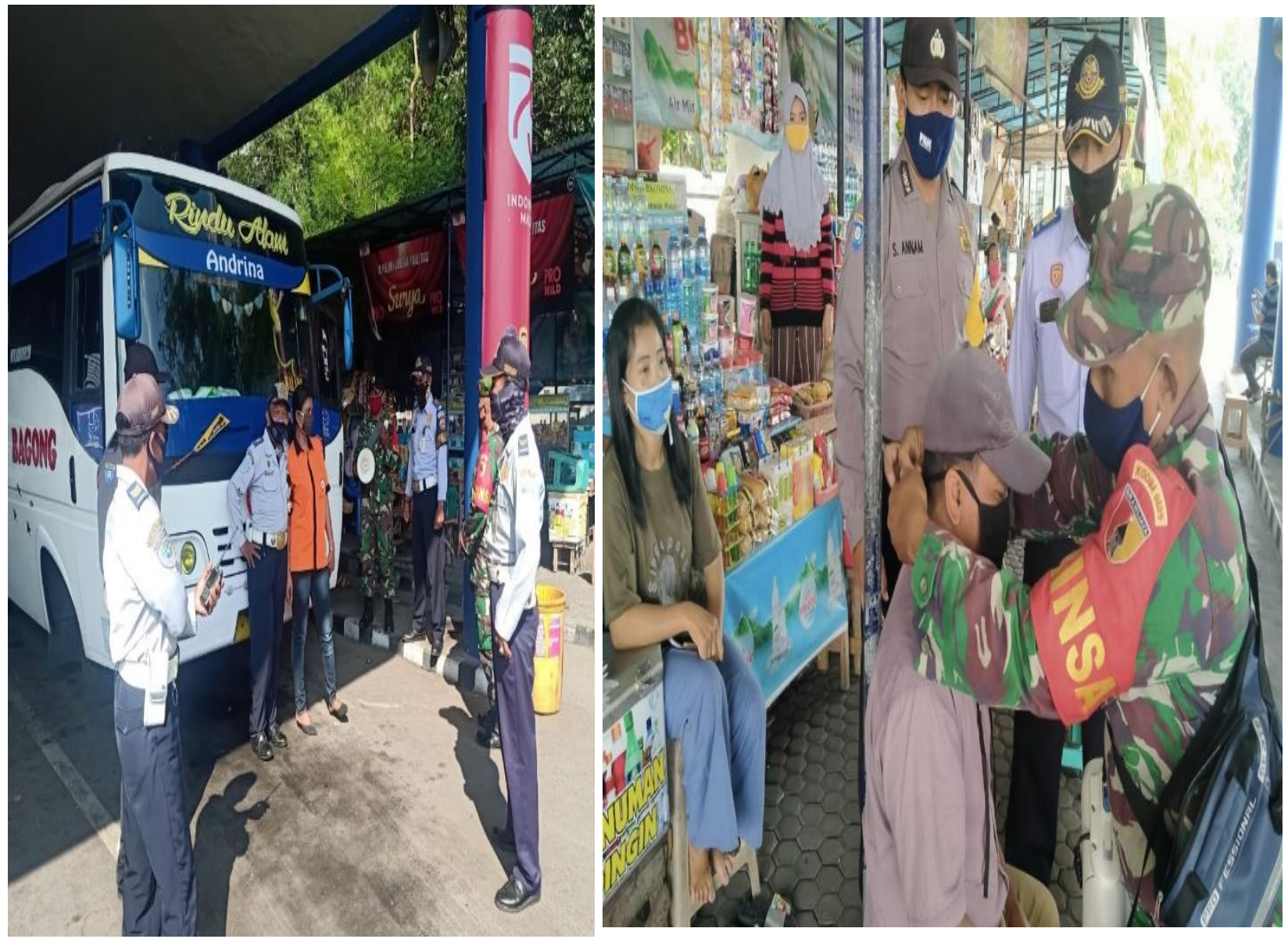

Gambar 1. Pendampingan kedisiplinan protokol kesehatan di Lokasi Terminal Kota 


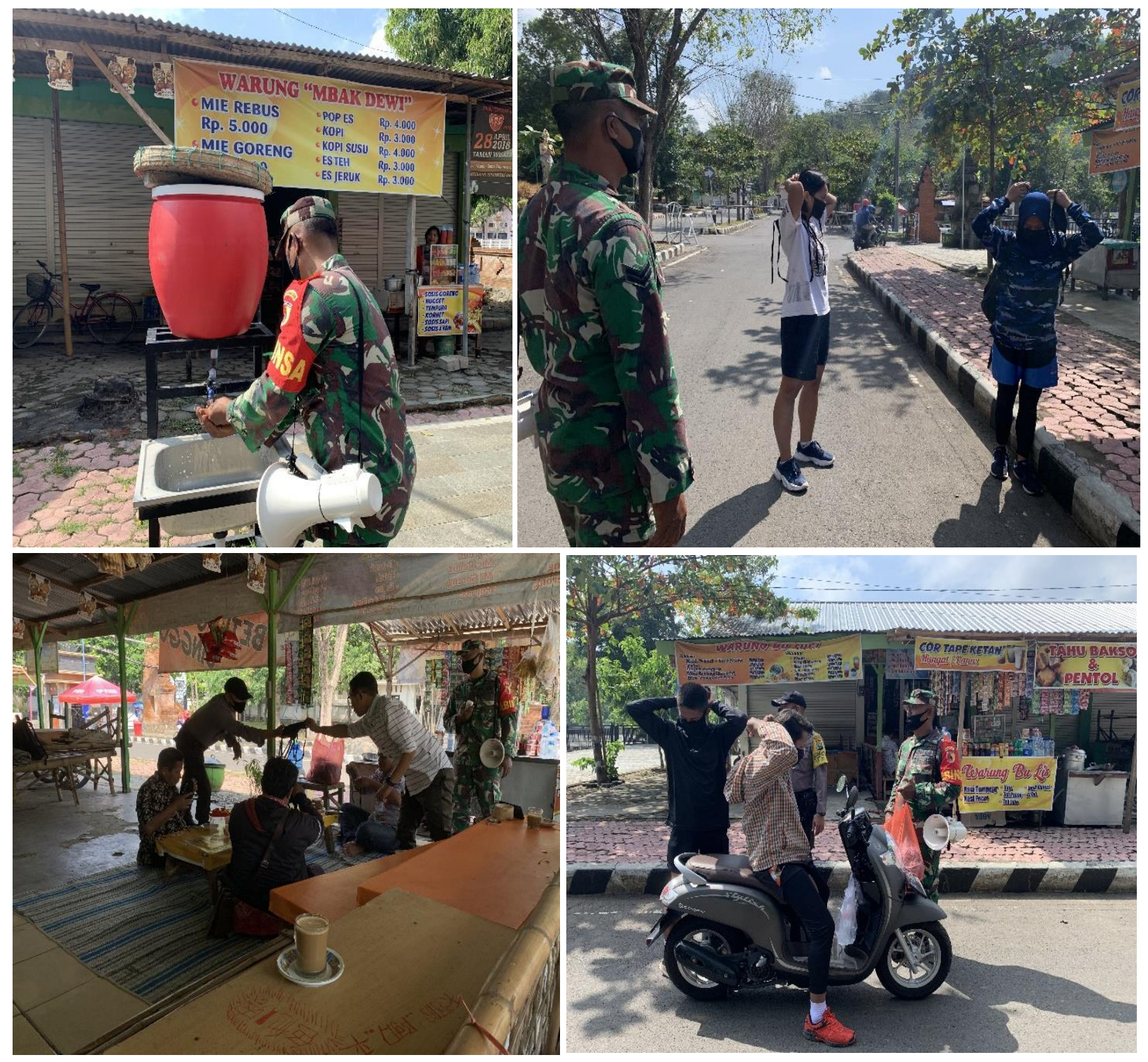

Gambar 2. Pendampingan kedisiplinan protokol kesehatan di Lokasi Obyek Wisata Goa Selomangkleng Kediri 

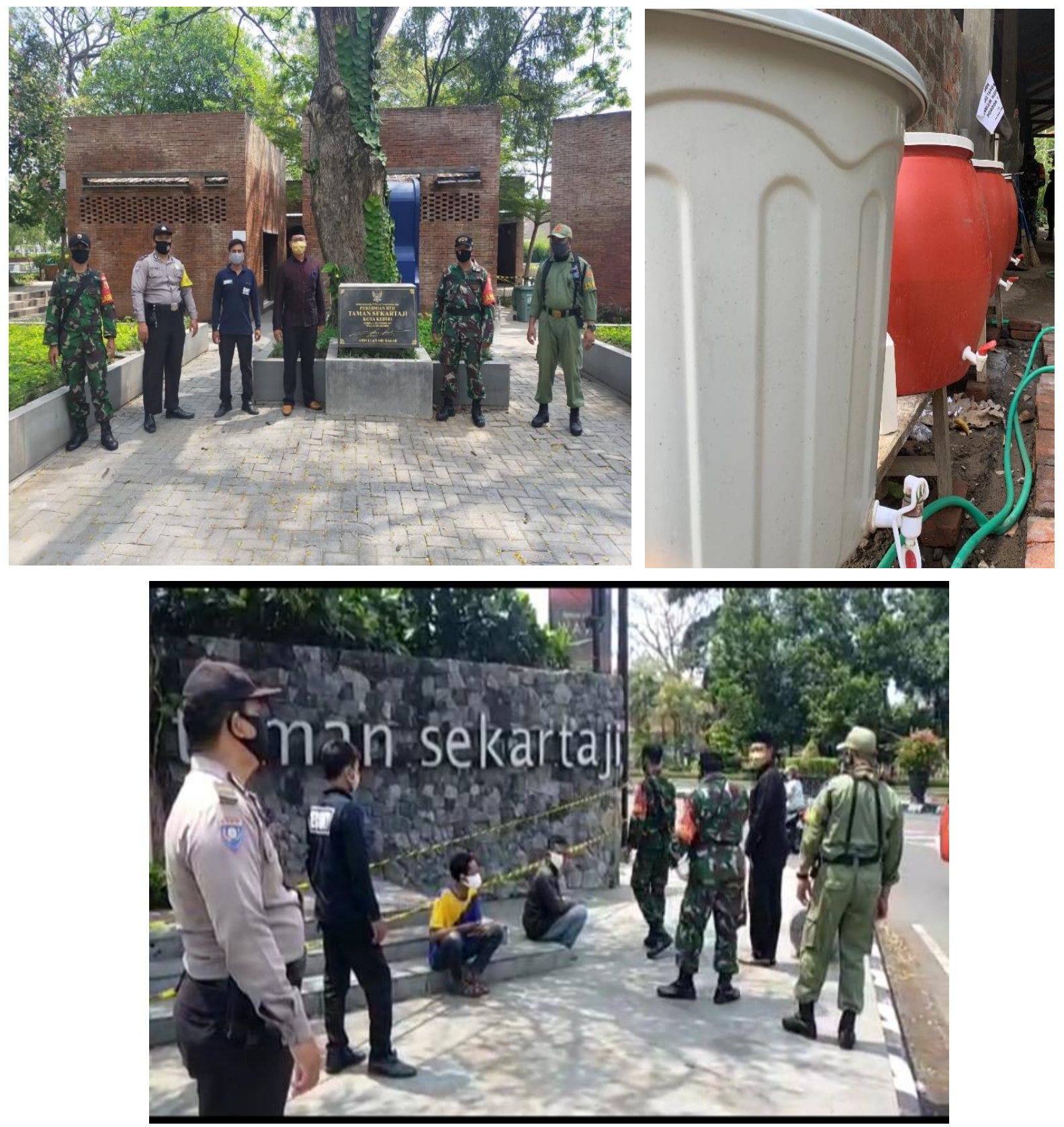

Gambar 3. Pendampingan kedisiplinan protokol kesehatan di Lokasi Taman Sekartaji Kediri 

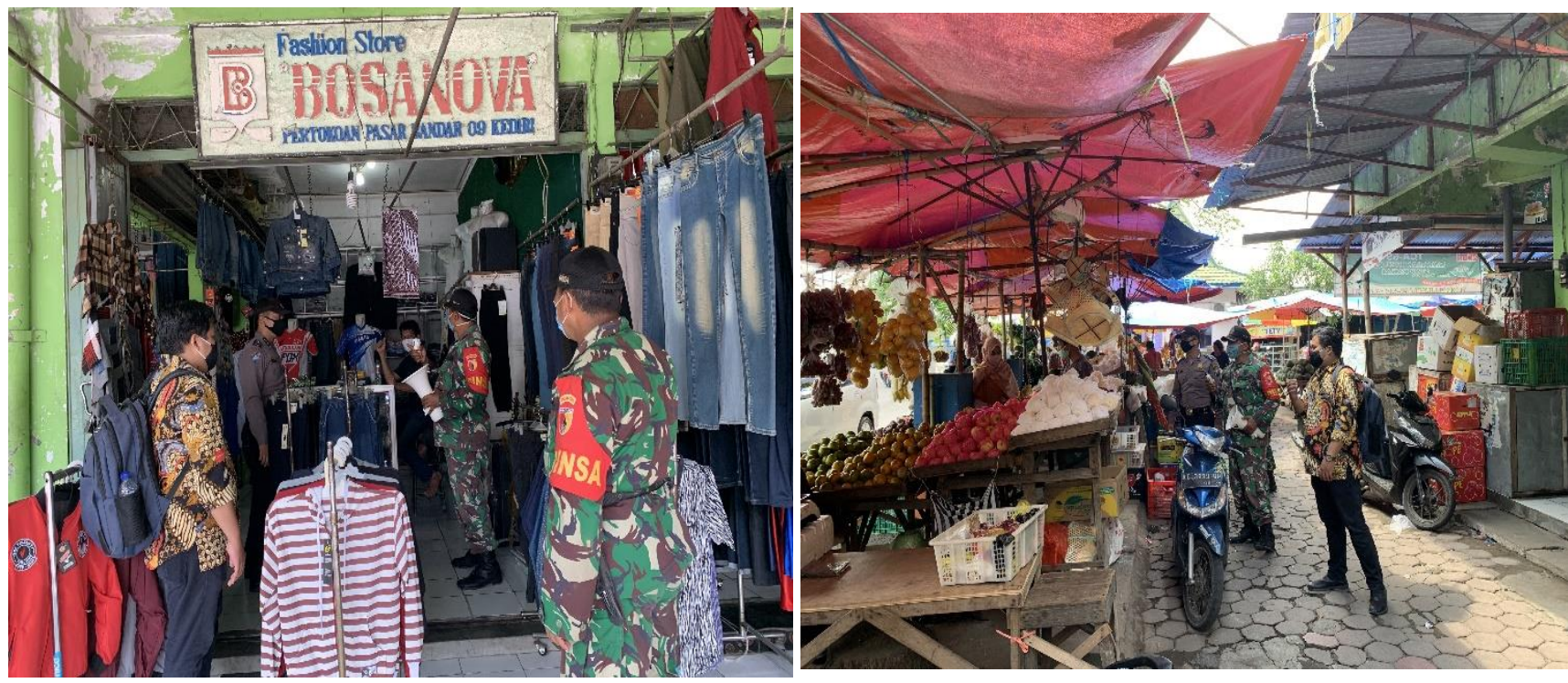

\section{Gambar 4. Pendampingan kedisiplinan protokol kesehatan di Lokasi Pasar Bandar Kediri}

Evaluasi kegiatan pendampingan masyarakat di era adaptasi kebiasaan baru guna menciptakan kawasan tangguh bencana Covid-19 yang berlokasi di 4 (empat) lokasi fasilitas publik Kota Kediri dilaksanakan setelah unsur-unsur terkait melaksanakan semua kegiatan pendampingan. Berdasarkan hasil evaluasi kegiatan masyarakat Kota Kediri belum sepenuhnya menerapkan protokol kesehatan sehingga nantinya diharapkan terbentuk kaderkader peduli bencana Covid-19. Mayoritas masyarakat di Kota Kediri masih beranggapan menjaga protokol kesehatan belum begitu penting. Dengan adanya pendampingan ini, akan lebih mendisiplinkan masyarakat sehingga kawasan-kawasan publik dapat waspada dan terciptanya kawasan tangguh bencana Covid-19

\section{DAFTAR PUSTAKA}

Herdiana, Dian. 2018. Sosialisasi Kebijakan Publik : Pengertian dan Konsep Dasar. Jurnal Ilmiah Wawasan Insan Akademik. Universitas Padjajaran. Vol 1(3) Hal. 13-26

Keputusan Menteri Kesehatan Republik Indonesia Nomor HK.01.07/MENKES/328/2020 Tentang Panduan Pencegahan Dan Pengendalian Corona Virus Disease 2019 (Covid-19) Di Tempat Kerja Perkantoran Dan Industri Dalam Mendukung Keberlangsungan Usaha Pada Situasi Pandemi 
MacIver, Robert Morrison. 2013. The Modern State ,London: Oxford University Press.

Rahardjo, Tumomo. 2010. Memahami Kemajemukan Masyarakat Indonesia (Perspektif Komunikasi Antarbudaya). Jurnal Ilmu Komunikasi FISIP UNDIP. Hal 1-10.

Kompas. 2020. Apa itu New Normal? Presiden Jokowi Sebut Hidup Berdamai dengan Covid19. Harian Kompas. Dilihat 26 Juli 2020. 